\title{
Self-consumption of electricity from renewable sources
}

\author{
Lead author: Joris Dehler (KIT)
}

Authoring team: Dogan Keles (KIT), Thomas Telsnig (IER), Benjamin Fleischer (IER), Manuel Baumann (KIT), David Fraboulet (KIC-IE/CEA), Aurélie Faure (IFRI), Wolf Fichtner (KIT)

Reviewer: Paul Deane (UCC), Volker Stelzer (KIT)

Legal Notice: Responsibility for the information and views set out in this paper lies entirely with the authors.

\section{Executive summary}

If the cost of energy production from renewable energy sources (RES) reduces below the level of electricity retail prices, self-consumption (SC) can contribute to market integration of RES. Support schemes such as feed-in tariffs could be phased out in view of parity of retail prices and RES production costs. In combination with electricity storage and demand response (DR), SC can facilitate the integration of variable renewables onto the grid and lower the overall costs of the energy system through load shifting particularly if storage and DR is managed using ICT and algorithms controlling charging cycles and usage of electric devices.

Some issues remain however: Self-consumption potential is limited without further technical enhancements in storage or DR solutions. To organize self-consumption efficiently, measures on the grid side and energy storage have to be taken. Enabling the grid to provide necessary information back to prosumers and vice versa, as well as developing economic ways of storing energy is key to unleashing the potential that lies within the transition from passive consumers to active prosumers. Different policies, such as the support of investments to storage installations, can foster those developments.

The impact of electricity retail prices has to be considered also. Self-consumption is profitable if the costs of locally produced RES are lower than the retail electricity price. There are, however, worries that a high penetration of self-consumption solutions might lead to an unfair distribution of network charges, taxes and levies even if storage and DR measures can lower additional costs arising from PV integration. Future energy policy can address the way how costs get allocated.

\section{Introduction}

A transition is expected from schemes supporting the use of renewable energy sources (RES) for electricity production towards market integration of RES. Self-consumption of RES can play its part: it offers benefits to political and economic stakeholders but is not broadly implemented yet due to the unclear profitability of self-consumption and cost of associated technologies.

In the context of this Brief, self-consumption of renewable energies is defined as electricity that is produced from RES, not injected to the distribution or transmission grid or instantaneously withdrawn from the grid $^{1}$ and consumed by the owner of the power production unit or by associates directly contracted to the producer.

Net metering schemes in general will not be discussed in this Brief, since they do not offer the benefits of self-consumption. To date, the technology with the highest share in distributed power generation is photovoltaics (PV). Therefore this is the technology to be addressed mainly in this Brief.

One of the major challenges to self-consumption in households is the disparities between power generation from PV and the actual demand. Most of

1 Such as a real time net metering scheme that has no offset between consumption and production 
the power production takes place when residents are not at home, pursuing their profession or other activities of daily life. Consequently, estimated SC potential varies between $17 \%$ and $44 \%$ depending on household-size and irradiation exposure without storage or load shifting measures (Luthander et al. 2015). Demand response represents the practice of managing electricity demand in a way that peak energy use is shifted to off-peak periods enabling higher rates of self-consumption or, more generally, the adaption of demand to grid issues. With electricity storage and demand response, rates of SC can be raised, and benefits in terms of mitigation of network costs due to the integration of PV could be achieved. There is still necessity for further research on the real potential of demand response and dedicated storage as figures differ largely between studies (Luthander et al. 2015). Figure 1 provides a schematic overview of SC issues and measures: load shifting can alter the electricity usage, while energy storage adapts PV production to the demand.

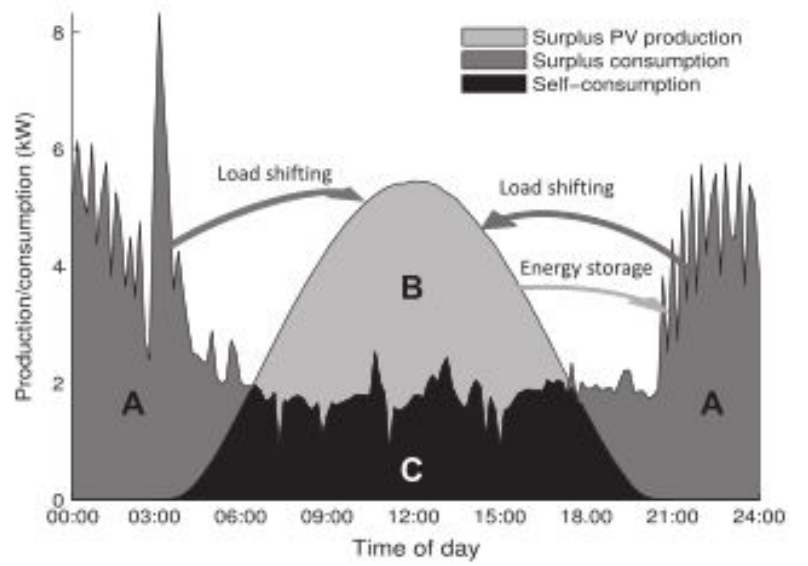

Figure 1: Schematic outline of daily net load $(A+C)$, net generation ( $B+C)$ and absolute selfconsumption (C) in a building with on-site PV ( source: Luthander et al. 2015).

Commercial enterprises can, due to the alignment of working hours with power production from PV, achieve higher rates of SC depending on the type of enterprise. Thus enterprises can profit largely from SC. In Germany, due to the issue of the distribution of costs of the energy transition, the State collects shares (30-40\%) of the RES levy from owners of larger PV units used for SC (see ANNEX I).

This Brief will address the political and economic benefits of SC before arising challenges are discussed together with possible policy measures. The issue of sharing costs of the electricity network and the distribution of taxes and different levies will be summarized and different options to reorganize the collection of network charges are discussed.

\section{Benefits}

Transition from support schemes (Feed-in Tariffs, Quotas) to market integration of RES In most EU Member States (MS) there are policy measures in place to support the market uptake of RES. In the long term support schemes are a means to integrate RES into the market for energy. While PV will not be able to compete against electricity wholesale prices in the medium-term (Pöyry 2014), SC is already competing with retail prices of electricity in some of the MS, where parity between retail prices and costs of PV is reached (e.g. Germany or Belgium; see ANNEX I) or will be reached soon. Savings compared to the retail price allow PV unit owners to develop a business case and could foster the development of PV penetration without the support of feed-in tariffs (FiT) or premiums even in the short and medium-term. Supporting SC hence is a means to smoothen the transition from old support schemes to the market integration of RES. For example, decreasing costs of PV and high retail prices led to grid parity in Germany and Belgium (see ANNEX I).

Empowering consumers and mobilizing new financial resources for RES

Enabling consumers to take responsibility for their energy consumption and production, SC can add to an efficient usage of energy. Encouraging the consumers to make active decisions on their habits of energy consumption can lead to greater awareness of energy usage and may help lead to a reduction in usage and to efforts to shift loads to times of high production.

The energy transition from conventional production to a RES oriented energy system requires substantial investment regarding networks and power production. By investing into small scale RES and technical solutions of SC, citizens and commercial enterprises can contribute to the high investment needs of the energy transition and profit from the avoidance of high electricity bills.

Grid relief and costs of electricity production Managed in the right way, self-consumption of RES can lower the pressure on the electricity grid of feed-in of electricity from RES in scenarios with a very high share of renewables. ${ }^{2}$ The exploitation of RES leads to high peaks in production and a low residual load during times of high wind speeds or intense sunshine hours. At other periods there may be little contribution of RES to cover electricity demand due to low wind speeds or cloudy days for PV production. In this context, there is evidence that self-consumption extended by storage and

${ }^{2}$ For an exemplary study on the grid-relief of SC please refer to ANNEX II, particularly "Residual demand and grid-injection profiles of reference households" 
demand response measures can reduce the additional integration costs ${ }^{3}$ of the integration of PV at high penetration levels ( $18 \%$ of total electricity production) by around $20 \%$ over all countries that were considered in the study. When taking grid extension on the distribution and transmission level into account the overall additional integration costs were estimated to decline from $2.6 \mathrm{c} € / \mathrm{kWh}$ without demand response and storage to $2.15 \mathrm{c} € / \mathrm{kWh}$ with these measures in place (Pudjianto et al. 2013). The additional integration costs of PV vary from country to country, being lower in southern European countries due to a better correspondence of demand and PV production profiles. However, the quoted study does not take into account costs that arise for consumers who have to invest to technological solutions as well. Arising challenges of a wide spread introduction of decentralized storage include the coordination of storage beneficial to the distribution and transmission grid.

\section{Challenges of self-consumption and policy options}

\section{Socio-economic limitations and technological solutions}

The main challenge for SC, particularly for selfconsumption of photovoltaics, is the diverging profiles of demand and production of electricity. While the production of electricity from PV obeys the course of the sun, demand peaks are particularly high in morning and evening hours when feed-in of PV power is low. Thus, the potential for SC is limited for residential buildings (estimated around $30 \%$ of the annual electricity consumption), if additional technological measures are not taken.

Increasing SC by behavioural change can only partially harness the potential of SC and faces difficulties: Whether prosumers will have the discipline to adapt to the production rhythm of PV electricity with relatively low incentives is a question waiting to be answered. On the other hand, system integration of mere SC without any technical enhancements is straightforward. Power self-consumed does not change the residual load, since it is neither consumed from the grid nor fedin. Therefore, integration costs of SC may remain low (see ANNEX II).

Without further adaptation of electricity provision and demand the residual load will not change. Therefore, SC without further adaptation measures will not unleash the full potential benefits of $\mathrm{SC}$ such as reducing the integration costs of PV. To exploit the full potential benefits to the distribution

\footnotetext{
3 Grid extension, balancing costs, conventional production capacities that must be covered with less electricity production, losses attributed to PV, higher operating reserve requirements
}

and transmission networks, technical means are necessary.

The measures to address disparities of profiles and to achieve a high share of SC are demand response and storage of electricity. This can be described as adapting the energy demand to production periods of PV or mitigating the energy output to peak demand by storing it until needed. Both technologies carry economical and technical issues to be overcome.

Grid integration issues of electricity storage Maximizing self-consumption through load shifting via batteries does not necessarily entail advantages for the electricity system in case of increasing capacities of distributed generation (DG): Direct battery charging strategies enable high selfconsumption rates as soon as there is a surplus of electricity. However, simple charging strategies can cause unpredictable DG production peaks as batteries at different sites are fully charged and the surplus is fed to the grid in an uncoordinated manner. It is possible to increase self-consumption rates and to decrease DG impact on distribution grids in parallel by the use of proper battery charging algorithms. Linear delayed charging for example is based on pre-setting a maximum state of charge increasing linearly over the day. It provides a possibility of reducing DG production peaks (Schott et al. 2014). Such grid optimized charge modes can help to improve local power quality and to provide transmission and distribution grid upgrade deferral in case of high local DG penetration.

\section{Electricity storage for SC - Financial issues}

As investments in storage capacities and demand response measures have to be taken by consumers, the affordability and ultimately the profitability of storage solutions is a major challenge to higher rates of self-consumption.

There are several battery storage technologies with different properties available to increase selfconsumption rates by conducting load shifting. Some of the most important technologies are inter alia Lithium-Ion batteries with different electrode combinations $\left(\mathrm{LiFePO}_{4}, \mathrm{LiCOO}_{2}\right.$, etc. $)$, Lead Acid batteries, Redox-Flow batteries (Zinc-Bromide, AllVanadium, etc.), flow batteries (VRB) and HighTemperature batteries ( $\mathrm{NaNiCl}, \mathrm{NaS}$ ) (Normark 2014) ${ }^{4}$. Remaining challenges for most existing battery technologies are cyclic and calendric life time, safety and environmental concerns (e.g. heavy metals) (Mulder et al. 2010). Yet the main problem of most available technologies is high initial investment costs leading to long amortization

\footnotetext{
${ }^{4}$ See the INSIGHT_E Policy Report "How can batteries support the EU electricity network?", available at http://insightenergy.org/static pages/publications
} 
times. In combination with missing business models this can be seen as the main barrier for further diffusion of battery storage from an economic perspective (Baumann et al. 2013, Thomas et al. 2014). This effect can be seen more precisely taking Levelized Costs Of Electricity (LCOE - cost of generating electricity, including initial capital cost, discount rates, operation and maintenance cost) into account. For example, a German domestic photovoltaic rooftop system without storage has a typical LCOE of 9-12 c€/kWh (Kost et al. 2013, Baumann et al. 2014). In combination with lead acid battery systems this can lead to a range of total LCOE from 22 to over $44 \mathrm{c} € / \mathrm{kWh}$ and with LiIron-phosphate top runner battery systems from $23 \mathrm{c} € / \mathrm{kWh}$ up to $47 \mathrm{c} € / \mathrm{kWh}$ with less performant systems (Stenzel et al. 2014). In this case grid parity is difficult to achieve. But new development in battery chemistry and economies of scale through electric vehicles can help to overcome some obstacles by the use of more effective materials and production strategies. Applying learning curves to different $\mathrm{Li}$-Ion systems based on battery market predictions showed that for example cell prices could fall from present $\sim 300 € / \mathrm{kWh}$ (Stenzel et al. 2014) to $200 € / \mathrm{kWh}$ in 2020 and to
$150 € / \mathrm{kWh}$ in 2030 (Baumann et al. 2014). At the same time spreads between rising electricity retail and falling PV self-consumption prices are increasing, making self-consumption through PV in combination with batteries more competitive in the future (Agora Energiewende 2014).

Demand response issues for self-consumption Demand response promotes better usage of energy and can reduce emissions by smoothening load curves or peaks and valleys of energy use and to better match consumption with intermittent DG, e.g. photovoltaics (Denholm et al. 2007). As mentioned previously, the potential for manual demand response is limited.

Other than energy storage systems, e.g. dedicated batteries or electric vehicles, there is potential for active demand side management of applications like heat pumps, washing machines or electric water heaters (Denholm et al. 2007). Running cycles of these technologies can be adapted to peak power production or to needs of the electricity grid - provided that there is the necessary feed-back from grid operators to consumers. Especially electric vehicles offer high load shifting potentials

\section{I mpact of storage on wholesale prices in an exemplary study on Germany's power market}

In the framework of this Brief a valuation of the impact of SC to wholesale prices in Germany with different load management regimes was conducted. ${ }^{5}$ To quantify the effect on the wholesale market, four different PV configurations were considered.

- REF: A reference PV system without storage and no self-consumption feeding the produced electricity into the grid

- SC: A PV system without storage covering the electricity demand (self-consumption) during daytime. The surplus energy is fed into the grid. No change of user-behaviour is assumed.

- SC-CC: A PV system with a storage system and a subsequent and chronological charging strategy at the time of demand exceeding generation. The surplus energy is fed into the grid

- SC-GR: A PV system with storage operating in grid-relief operation mode. The surplus energy is fed into the grid.

System costs of the REF and the SC variation are the same in the electricity market calculation since there is no change of the residual load and consequently no deviation in unit commitment. In the SC-CC and SC-GR variation the annual cost of the small-scale storage systems in households (420.96 million Euros) have to be added to the result from the market model. In both variations considering storage, the savings in the total system could not cover the additional spending on the storage units. The savings in the SC-GR variation are 174.86 million Euros beyond the savings in the SC-CC variation. Table 1 shows the impact of the scenario variations the deviation of system costs from the self-consumption variations to the REF variation. The analysis considers only the effects of different self-consumption strategies on the wholesale market. Additional cost saving potential can be expected at electricity grid level which is not covered in the current analysis. Moreover, the household electricity demand structure was derived from an aggregated synthetic load profile. Detailed modelling of different household consumption patterns should be considered in further studies.

Table 1: I mpacts of self-consumption and total system costs in the German power supply sector for 2030

\begin{tabular}{|cccrrr|} 
Scenario 2030 & & REF & SC & SC-CC & SC-GR \\
\hline Deviation of system costs from REF & & & & & \\
System cost & {$\left[€ /\right.$ a $\left.10^{6}\right]$} & 0.00 & 0.00 & -151.86 & -326.72 \\
Annual Cost storage & {$\left[€ /\right.$ a $\left.10^{6}\right]$} & 0.00 & 0.00 & 420.96 & 420.96 \\
Deviation Total cost 2030 & {$\left[€ /\right.$ a $\left.10^{6}\right]$} & 0.00 & 0.00 & $\mathbf{2 9 6 . 1 0}$ & $\mathbf{9 4 . 2 4}$ \\
\hline
\end{tabular}

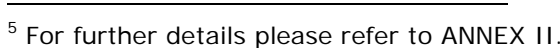


(Agora Energiewende 2014). A $10 \%$ EV market share in Germany for example with $50 \%$ of electric vehicles simultaneously connected to the grid via typical $3.6 \mathrm{~kW}$-household sockets offers a peak power/load of $7.6 \mathrm{GW}$ and about $22 \mathrm{GWh} / \mathrm{d}$ for load shifting (based on daily trips and a mid-sized battery electric vehicle with a $25 \mathrm{kWh}$ battery) (Baumann et al. 2012). Relevant technologies for DR are smart metering, load limiters or direct load control (Strbac 2008). DSM can also be combined with energy storage technologies in order to further increase self-consumption. The low penetration of smart meters and load control devices is hindering the development of SC, as well as the management of SC beneficial to the electricity grid (Strbac 2008).

Subsidies for storage and technical solutions To support the market uptake of storage and demand management solutions, thereby contributing to self-consumption indirectly, it might be feasible to support investments of prosumers in storage technologies. Similar to the fast development of PV-cells, such an incentive might accelerate the development of storage and demand management, making these technologies financially attractive even without subsidies in the long run. German policy can serve as an example for the support of storage with loans with low interest and investment subsidies (see ANNEX I).

To make sure that benefits of SC get realized, a subsidy scheme for storage should ensure that peak load is managed in a way that the electricity network benefits. As we have argued, uncoordinated charging of batteries can have a negative effect on grid balancing greater than PV integration in itself.

Electricity storage can fulfil balancing tasks for the grid, if regulations allow them to provide such energy flows (Hollinger et al. 2013). This might extend the current business models of RES-units.

Indirectly pushing the progress of SC by supporting research and development activities for storage and demand management is another option. By enabling companies and research facilities to explore and invent new technologies, prices for applications can reduce making such solutions attractive to prosumers.

\section{Direct support by premiums on SC}

Supporting SC directly, a premium on every selfconsumed kWh is a straight forward possibility to reward consumer engagement in load shifting measures. A premium promotes the management of consumption according to production. This also might include the purchase of storage or demand management solutions, if they appear to be an economic feasible step towards higher SC. For example, Germany made use of this option until PV reached grid parity in 2012 . The UK has a FiT- scheme also remunerating generated and selfconsumed electricity (see ANNEX I). In an attempt to exploit emerging market opportunities from the UK support scheme, major companies are launching PV storage solutions in the UK market from 2015 on (Colthorpe 2014).

Energy efficiency measures however may be compromised, since the consumption of electricity gets remunerated by a premium. It should be ensured that charging cycles of batteries get adapted to the needs of the grid.

Support measures on the grid-side: promote ICT to accelerate development

As the development of a high share of SC depends on the evolution of ICT in connection with the electricity grid, another measure is to support the fast implementation of "smart" meters and network management solutions. This way, batteries and home applications of prosumers can react flexibly to management issues of the grid, thereby lowering grid integration costs of RES contributing to a flattened demand and supply curve as argued before. An example may be the promotion of early warnings from a prosumer about its future power request or injection to the network in order to enable the network operator to take precursory measures.

Reduce the amount of electricity allowed to be fed into the grid or compensated by feed-in tariffs

In order to reinforce measures taken by a prosumer, there is the option to limit the amount of electricity that is allowed to be fed into the grid. This could be a general limit to fed-in electricity or the flexible possibility to lower input from specific prosumers by the DSOs. Such a limit may encourage the discipline of the prosumer to selfconsume the produced energy.

A prerequisite for production units larger than $100 \mathrm{kWp}$ in Germany is that they are controllable by the DSOs. However, in Germany, the possibility to take PV units off the grid is not meant to be an incentive for self-consumption, as switched-off capacity gets remunerated.

\section{The issue of sharing grid costs, levies and taxes; policy options}

The structure of electricity retail prices

Generally, retail prices for electricity are on the rise and expected to increase further in future. The retail price can be divided in three major portions. For the average household prices in Europe the component of energy and supply costs decreased (from $8.1 \mathrm{c} € / \mathrm{kWh}$ in 2008 to $7.7 \mathrm{c} € / \mathrm{kWh}$ in 2012), 
while the component of taxes and levies increased ( $5.1 \mathrm{c} € / \mathrm{kWh}$ to $6.7 \mathrm{c} € / \mathrm{kWh}$ ) and the share of the network slightly increased $(4.65 \mathrm{c} € / \mathrm{kWh}$ to $5.1 \mathrm{c} € / \mathrm{kWh}$ ) (EURELECTRIC 2014). End-user prices vary largely between the Member States being the lowest in Bulgaria (2012: $8.26 \mathrm{c} € / \mathrm{kWh}$ ) and highest in Denmark (29.97 c€/kWh) (EUROSTAT).

Estimated additional integration costs of PV consist largely of additional conventional capacity costs (Pudjianto et al. 2013). At high penetration of PV, additional capacity costs vary between $1.6 \mathrm{c} € / \mathrm{kWh}$ in Portugal and $0.9 \mathrm{c} € / \mathrm{kWh}$ in Greece. Those costs can be mitigated or lowered by self-consumption (Pudjianto et al. 2013).

\section{The issue of distribution of grid costs}

Network charges in Europe are mainly covered depending on the volume of the electricity demand of the respective end-user. An advantage lies in the incentive sent to reduce the electricity demand. However they do not account for the actual cost structure of DSOs and TSOs, which mainly depends on the maximal load that is obtained at once (EURELECTRIC 2013). In addition, those costs are avoided by self-consumers. Thus, there is concern that intensified SC will lead to an unfair distribution of grid costs because self-consumers still need the grid infrastructure but obtain less energy from the grid, thereby not paying the same amount of grid fees in total.

The estimated share in the modelling exercise of Pudjianto et al. (2013) of necessary additional transmission grid extension and operating costs appears to be rather small even at high penetration of PV (less than $0.05 \mathrm{c} € / \mathrm{kWh}$ by $2020,0.28 \mathrm{c} € / \mathrm{kWh}$ by 2030). The distribution network costs vary by Member State, being the highest in Belgium at high penetration of PV $(0.9 \mathrm{c} € / \mathrm{kWh})$. Additional costs can be reduced by demand response and storage (e.g. to $0.6 \mathrm{c} € / \mathrm{kWh}$ for distribution network costs in Belgium) (Pudjianto et al. 2013).

A factor that was not considered in the study of Pudjianto et al. (2013) is that solutions of selfconsumption profit largely from the "smartening" of the power grid. Smart meters and communication devices enable self-consumption; on the other hand they create costs. Ultimately, the profitability of SC depends on how those costs get allocated. If those costs get paid by way of adding it to the electricity bill by volume, then they get allocated to a large portion of customers that do not profit from the efficient self-consumption (SunEdison 2011).

\section{Distribution of other levies and taxes}

The growing share of taxes and levies contributes to the profitability of SC in terms of the avoidance of those additional costs by consuming the electricity self-produced. Thereby, levies for PV support can be lowered, if units eligible for FiT support self-consume the produced electricity instead of feeding in. On the other hand, SC can lead to an altered or even unfair distribution of those charges. Levies for combined heat and power (CHP) and other policy support costs make up for a portion of the electricity retail price for households and industrial customers (EURELECTRIC 2014). Taxes on electricity could also be avoided, thereby lowering public revenues.

The structure of retail prices of energy might be a source of insecurity for long-term investments into measures for self-consumption. Since a large portion of the retail price of electricity are taxes and levies and the profitability of self-consumption depends largely on the retail price, changes to policies and taxes endanger investments. An example from Germany illustrates that the net present value of a solar installation decreases significantly with lower taxes and duties (REC Solar Germany GmbH 2014).

Adapting grid tariffs to changing conditions A fixed grid tariff depending only on the maximum load as an attempt to solve the issue of the distribution of costs takes the actual cost structure into account. This however decreases the incentive to save energy and to use energy efficient products. Thus other approaches might be favourable in order to address both, the distribution of costs and incentives for energy efficiency. There are different approaches to bypass those shortcomings. EURELECTRIC (2013) proposes network tariffs comprised of two parts: a part that accounts for the capacity held available and an energy component. Alternatively, EURELECTRIC, as well as German Agora Energiewende (2014) propose time-varying grid charges to fairly distribute costs to all stakeholders. At time of peak load, grid charges should be higher than in times of a low load. This way, incentives for smoothening production and consumption can be set, as well as stimuli for SC at times of peak feed-in. On the other hand, load shifting by large consumers such as industrial plants can be incentivized, since price signals will raise profits of load adapted behaviour.

Smart meters and the development of ICT can promote the development of tariffs that set incentives to shift load to different hours but bear additional costs to be considered.

Changing the way grid costs get distributed may have an impact on grid parity of the different technologies. Benefits from the impact of SC to peak loads must be carefully considered when deciding on reforming grid tariffs.

\section{Conclusions}

Energy Policies and prerequisites in each MS of the EU are diverse. Introducing specific policies supporting SC should take into account the different 
structures of markets and the state of development of the RES sector, in particular the probability of reaching grid parity of different technologies.

To foster SC the national legal framework in each Member State is to be revised. Potential barriers must be analysed carefully and removed if there is no reasonable justification for those measures. Apart from the review of current legislation, there are different options to support the market uptake of SC.

Since renewable energies and especially PV are well on track to reach grid parity within the next years all over Europe, direct support schemes such as a premium on SC might not be necessary in most Member States to foster SC. An additional downside of premiums on self-consumption is the potential interference with energy efficiency efforts: If the mere consumption of energy gets remunerated by a premium, this will not encourage energy efficiency measures.

Supporting the usage of energy storage solutions and demand management might be a good measure to promote both, the development of the technologies and SC. Furthermore, storage can contribute to balancing measures on the grid, if incentives are set right. The implementation of management solutions such as dedicated charging algorithms to an electricity system with a high share of PV appears to be crucial for enabling the full benefits to the grid from SC. Similar to the introduction of FiTs to promote RES, support of technological solutions can lead to market maturity of storage and DSM technologies.

Supporting SC on the large scale and benefits from the balancing potentials of SC using storage will require enablers such as smart grid technologies and dynamic electricity tariffs.

A delicate topic is the distribution of the costs, be it costs of the power grid or additional production costs of RES. SC tends to reallocate costs from some prosumers that can afford the necessary investments to consumers that have to receive their power only from the common grid. The latter being charged a higher share of grid costs, levies and taxes. Interesting proposals to change the collection of grid costs such as time-varying grid charges or charges split by volume and maximum load were made by different institutions (Agora Energiewende 2014, EURELECTRIC 2013).

For further reading or information, please visit www.insightenergy.org

\section{Sources:}

ACER (2014): Annual Report on the Results of Monitoring the Internal Electricity and Natural Gas Markets in 2013.

http://www.acer.europa.eu/Official documents/Act s_of the_Agency/Publication/ACER_Market_Monitor ing Report 2014.pdf.
Agora Energiewende (2014): Stromspeicher in der Energiewende - Untersuchung zum Bedarf an neuen Stromspeichern in Deutschland für den Erzeugungsausgleich, Systemdienstleistungen und im Verteilnetz. Berlin.

Agora Energiewende (2014): Netzentgelte in Deutschland.

http:// www.raponline.org/document/download/id/ 7 431.

Baumann, M., Poncette, D., and Zimmermann, B (2014): Evaluation of calculation methods, models and data sources for life cycle costing on the example of stationary battery systems. Presented at the 8th Society and Materials International Conference - SAM 8, Belgium, 21.052014.

Baumann, M., Simon, B. Dura, H. and Weil, M. (2012): The contribution of electric vehicles to the changes of airborne emissions. Presented at the IEEE Energycon 2012, Florence.

Baumann, M., Zimmermann, B. and Dura, H. (2013): A comparative probabilistic economic analysis of selected stationary battery systems for grid applications. Presented at the International Conference on CLEAN ELECTRICAL POWER Renewable Energy Resources Impact, Alghero, Sardinia - Italy.

Beurskens, L. and Hekkenberg, M. (2011): Renewable Energy Projections as Published in the National Renewable Energy Action Plans of the European Member States - Covering all 27 EU Member States, European Environment Agency and Energy research Centre of the Netherlands, ECN-E-10-069.

Bundesnetzagentur (2014) : List of Power Plants, published online:

http://www. bundesnetzagentur. de/cln 1411/EN/Ar eas/Energy/Companies/SpecialTopics/PowerPlantLis t/PubliPowerPlantList node.html, Bonn.

Colthorpe, A. ( 2014) : International firms target UK for 2015 energy storage push.

http://www.solarpowerportal.co.uk/editors_blog/int ernational firms target uk for 2015 energy stora ge_push 2694. ^

Denholm, P. and Margolis, R. (2007):

Evaluating the limits of solar photovoltaics (PV) in electric power systems utilizing energy storage and other enabling technologies, Energy Policy 35, Issue 9, 4424-4433.

EURELECTRIC (2013): Network tariff structure for a smart energy system. http://www. eurelectric.org/media/80239/20130409 network-tariffs-paper final to publish-2013-0300409-01-e.pdf.

EURELECTRIC (2014): Analysis of European Power Increase Drivers. 
http://www. eurelectric.org/media/131606/prices_st udy final-2014-2500-0001-01-e.pdf

German transmission system operators (2014): Grid Development Plan 2014, second draft, Berlin/Dortmund/Bayreuth/Stuttgart.

Hollinger, R., Wille-Haussmann, B., Erge, T., Sönnichsen, J., Stillahn, T. and Kreifels, N., (2013): $\quad$ Speicherstudie 2013. http://www. ise. fraunhofer.de/de/veroeffentlichunge $\mathrm{n} /$ veroeffentlichungen-pdf-dateien/studien-undkonzeptpapiere/speicherstudie-2013.pdf.

Hoppmann, J., Volland, J., Schmidt, T., Hoffmann, V. (2014): The economic viability of battery storage for residential solar photovoltaic systems - A review and a simulation model, Renewable and Sustainable Energy Reviews 39 (2014) 1101-1118, Zurich/Cambridge.

Jülch, Telsnig, T., Schulz, M., Hartmann, N., Thomsen, J., Eltrop, L. and Schlegl, T.(2015): A holistic comparative analysis of different storage systems using levelized cost storage and life cycle indicators, Conference paper for the $9^{\text {th }}$ International Renewable Energy Storage Conference (IRES).

Kost, C., Mayer, J., Thomsen J., Hartmann, N., Senkpiel, C., Philipps, S., Nold, S., Lude, S. and Schlegl, T. (2013): Stromgestehungkosten erneuerbarer Energien. FRAUNHOFER-INSTITUT FÜR SOLARE ENERGIESYSTEME ISE.

Luthander, R., Widén, J., Nilsson, D. and Palm, J. (2015): Photovoltaic self-consumption in buildings: A review. Appl. Energy, vol. 142, pp. 8094.

Moshövel, J. Kairies, K.-P., Magnor, D. Leuthold, M., Bost, M., Gährs, S., Szczechowicz, E., Cramer, M. and Sauer, D. (2014): Analysis of the maximal possible grid relief from PV-peak-power impacts by using storage systems for increased self-consumption, Applied Energy 137 (2015) 567-575.

Mulder, G., De Ridder, F. and Six, D. (2010): Electricity storage for grid-connected household dwellings with PV panels, Solar Energy 84 (2010) 1284-1293.

Normark, B. and Faure, A. (2014): How can batteries support the EU electricity network? http://insightenergy.org/static_pages/publications

Pause, F. (2013): Alternative policies for PV deployment.

http://www. pvparity.eu/results/alternative-supportschemes/.

Platts (2012): World Electric Power Plants Database - Europe 2012, McGraw Hill Financial, New York.

Pöyry (2014): Is the end in sight for renewable subsidies? http://www. poyry.com/sites/default/files/imce/files $\angle$ pov renewable subsidies pn0019 v1 web.pdf

Pudjianto,D., Djapic, P., Dragovic, J. and Strbac, G. (2013): Grid Integration Cost of Photovoltaic Power Generation. http://www. pvparity.eu/results/cost-and-benefitsof-pv-grid-integration/

REC Solar Germany GmbH (2014): Study on the Profitability of commercial self-consumption Solar Installations in Germany. http://www. recgroup.com/Documents/Downloadce nter/Solar\% 20product\% 20downloads/Solar\% 20Whi tepapers/Solar Study Self Consumption/REC Stud y_Self_Consumption_in_Germany_Report_EN_Web 20140317.pdf?epslānguage $=$ en

Schlesinger M., Lindenberger, D. and Lutz, C. (2014): Development of Energy Markets - Energy Reference Forecast, Project No. 57/12 Study commissioned by the German Federal Ministry of Economics and Technology, Basle/Cologne/Osnabrück, June.

Schott, B. Binder, J., Felder, M., Matthis, B., Capota, M. and Danzer, M. (2014): Optimierung der Systemintegration fluktuierender Stromerzeugung aus erneuerbaren Energien am Beispiel der Photovoltaik auf Niederspannungsebene - Untersuchungen zu Möglichkeiten und Potenzialen zukünftiger Energieversorgungsstrukturen. Zentrum für Sonnenenergie - und Wasserstoff - Forschung Baden - Württemberg (ZSW).

Stenzel, P., Baumann, M., and Fleer, J . (2014): Database development and evaluation for technoeconomic assessments of electrochemical energy storage systems. Presented at the EnergCon, Dubrovnik, Croatia, 2014.

Strbac; G. (2008): Demand side management: Benefits and challenges, Energy Policy 36, Issue 12, 4419-4426.

SunEdison (2011): ENABLING THE EUROPEAN CONSUMER TO GENERATE POWER FOR SELFCONSUMPTION.

http://www. sunedison.es/docs/SunEdison_PV_Selfconsumption Study high resolution \% $2813 \quad \overline{M b} \%$ 29.pdf

Sun Ninghong (2013): Model-based investigation of the electricity market: unit commitment and power plant investments, University of Stuttgart, Institute for Energy Economics and the Rational Use of Energy, Stuttgart.

Thomas, W., Detlef, S. and Meister, M. (2014): Facilitating energy storage to allow high penetration of variable Renewable Energy. European Union. 


\section{ANNEX I: Case Studies}

For a better understanding of the matter and since legislation in the different Member States diverges, we provide case studies for Belgium, France, Germany and the United Kingdom.

\section{Case Study: Belgium}

Summary: In early 2015, RES electric power accounts for more than $15 \%$, of which PV exceeds 3GW peak. A net metering scheme is in place since 2012, when grid parity was reached. Feet-in tariffs were decreased.

\begin{tabular}{|c|c|c|}
\hline Case Study SC & Belgium & Sources \\
\hline Key facts & $\begin{array}{l}\text { PV national target 2020: } 1.34 \mathrm{GWp} \text {. } \\
\begin{array}{l}\text { PV installed: } 3.1 \mathrm{GWp} \text { (end 2014) } \\
\text { o Above } 10 \mathrm{kWp}: 1.23 \mathrm{GWp} \\
\text { o Below } 10 \mathrm{kWp}: 1.87 \mathrm{GWp}\end{array}\end{array}$ & $\begin{array}{l}\text { National } \\
\text { renewable } \\
\text { action plan }\end{array}$ \\
\hline Policies relevant to SC & $\begin{array}{l}\text { - Support for RES by a quota system based on the } \\
\text { - } \quad \text { Net metering scheme in place. Since grid parity is } \\
\text { reached, this is fostering the installation of PV. } \\
\text { - Support for initial investments in energy } \\
\text { technologies in residential, industrial as well as } \\
\text { service sector buildings. The support depends on } \\
\text { the region, since those are responsible for the } \\
\text { details of support schemes based on a national } \\
\text { framework. }\end{array}$ & res-legal.eu \\
\hline Relevant market data & 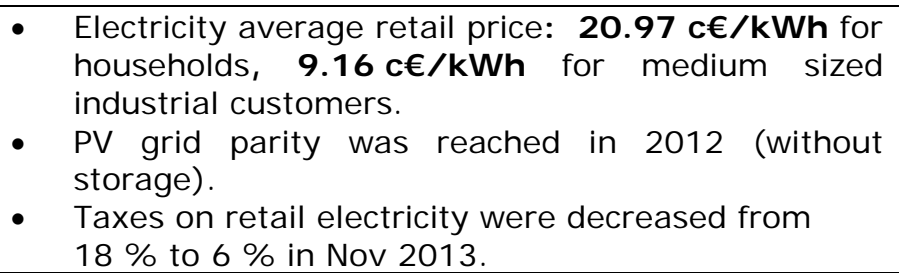 & $\begin{array}{l}\text { EUROSTAT, } \\
\text { PVparity.eu }\end{array}$ \\
\hline Economic and grid impact of RES & $\begin{array}{l}\text { - Estimated additional costs of grid integration of PV } \\
\text { at high penetration levels ( } 18 \% \text { ): } \mathbf{2 . 6} \mathbf{c} \boldsymbol{€} / \mathbf{~ k W h} \text {. } \\
\text { Possible reduction with demand response } \\
\text { measures/SC to } \mathbf{2 . 1 5} \mathbf{c} \boldsymbol{€} / \mathbf{~ k W h} \text {. }\end{array}$ & PVparity.eu \\
\hline
\end{tabular}


Case Study: France

Summary: France has a low PV penetration ( $<10 \%$ installed generation), despite good irradiation. France's 2020 National Energy Plan PV objectives are overachieved. French regulatory framework allows selling production at FIT or surplus at FIT depending on the installation. Grid parity is foreseen for mid-2018.

\begin{tabular}{|c|c|c|}
\hline Case Study SC & France & Sources \\
\hline Key facts & $\begin{array}{l}\text { PV national target 2020: } 5.4 \text { GWp. } \\
\text { - PV installed: } 5.6 \mathrm{GWp} \text { (end 2014) } \\
\text { o Residential: } 17 \% \\
\text { o } \% \\
\text { o Cound mounted: close to } 50 \% \\
\text { o Industrial: } 0 \% \\
\end{array}$ & $\begin{array}{l}\text { Ministry of energy, } \\
\text { epia.org }\end{array}$ \\
\hline Policies relevant to SC & $\begin{array}{l}\text { - Support for RES: FiT scheme feed-in } \\
\text { compensations varying between } 6.62 \mathrm{c} € / \mathrm{kWh} \\
\text { and } 26.55 \mathrm{c} € / \mathrm{kWh} \text { depending on the size of } \\
\text { the unit. } \\
\text { Under decree law } \mathrm{n}^{\circ} 2008-386-23 \mathrm{rd} \text { april } \\
2008 \text { - A self-consumption convention can be } \\
\text { signed with DSO, whereby all electricity } \\
\text { produced is consumed on site. } \\
\text { Exoneration on Renewable and Social } \\
\text { Surcharge ("Contribution au Service Public de } \\
\text { l'Electricité"-CSPE) - equivalent to } \\
\text { 1.95 c€/kWh. } \\
\text { Exoneration on Final Tax on Electricity } \\
\text { Consumption (TICFE) - Municipal Tax - } \\
\text { equivalent to 0.05 c€/kWh exoneration for } \\
\text { installations above } 250 \mathrm{~kW} \text {. } \\
\text { Exoneration on VAT - equivalent to } 20 \% \text { of } \\
\text { self-consumed energy charges. }\end{array}$ & Ministry of energy \\
\hline Relevant market data & 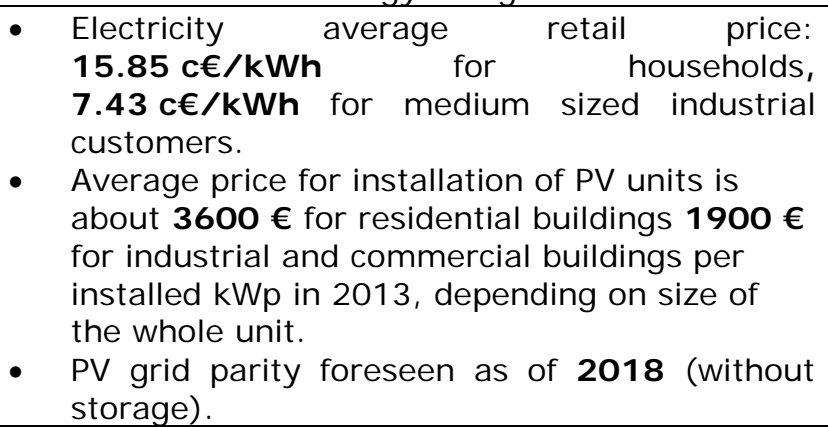 & EUROSTAT, PVparity.eu, \\
\hline $\begin{array}{l}\text { Economic and grid impact of } \\
\text { RES }\end{array}$ & $\begin{array}{l}\text { - Estimated additional costs of grid integration } \\
\text { of PV at high penetration levels }(18 \%) \text { : } \\
\mathbf{2 . 2 9} \mathbf{c} € / \mathbf{~} \mathbf{W h} \text {. } \\
\text { Possible reduction with demand response } \\
\text { measures/SC to } \mathbf{1 . 7 2} \mathbf{c} € / \mathbf{~ k W h} \text {. }\end{array}$ & PVparity.eu \\
\hline
\end{tabular}




\section{Case Study: Germany}

Summary: Germany has a high PV penetration. Germany's 2020 National Energy Plan PV objectives may be achieved. German regulatory framework allows selling production at FIT or surplus at FIT depending on the installation. Grid parity is reached since 2012 due to high electricity retail prices. SC is allowed and was supported until 2012. Measures fostering storage are in place.

\begin{tabular}{|c|c|c|}
\hline Case Study SC & Germany & Sources \\
\hline Key facts & $\begin{array}{l}\text { PV national target 2020: } 51.75 \text { GWp. } \\
\begin{array}{c}\text { PV installed: } 35.9 \text { GWp (end 2014) } \\
\text { o Residential: } 18 \% \\
\text { o Ground mounted: } 35 \% \\
\text { o Commercial: } 34 \% \\
\text { o Industrial: } 13 \%\end{array}\end{array}$ & $\begin{array}{l}\text { erneuerbare-energien.de, } \\
\text { epia.org }\end{array}$ \\
\hline Policies relevant to SC & $\begin{array}{l}\text { - Support for RES: FiT scheme with relatively low } \\
\text { feed-in compensations between } 8.65 \mathrm{c} / \mathrm{kWh} \\
\text { and } 12.50 \mathrm{c} / \mathrm{kWh} \text { depending on the size of the } \\
\text { unit. } \\
\text { Until } \mathbf{2 0 1 2} \text {, SC was supported by premiums. } \\
\text { Since grid parity of PV was reached in 2012, } \\
\text { there is no direct support for self-consumption } \\
\text { in place anymore. } \\
\text { - Since May 2013, there is a support scheme } \\
\text { for storage in place. For PV smaller than } \\
30 \mathrm{kWp} \text {, investment to storage is supported by } \\
\text { up to } 30 \% \text {. Furthermore, there is a } \\
\text { programme of KfW-Bank for loans for } \\
\text { investment to storage. Technical measures for } \\
\text { grid release management are required. } \\
\text { Since August } \mathbf{2 0 1 4}, 30-40 \% \text { of the EEG levy } \\
\text { is to be paid on self-consumed energy for PV- } \\
\text { units bigger than } 10 \mathrm{kWp.}\end{array}$ & $\begin{array}{l}\text { bundesnetzagentur.de, } \\
\text { bmwi.de }\end{array}$ \\
\hline Relevant market data & $\begin{array}{l}\text { - Electricity average retail price: } \mathbf{2 9 . 8 1} \mathbf{c} € / \mathbf{k W h} \\
\text { for households, } \mathbf{8 . 4 4} \mathbf{c} € / \mathbf{~ k W h ~ f o r ~ m e d i u m ~} \\
\text { sized industrial customers. } \\
\text { Average price for installation of PV units is } \\
\text { about } \mathbf{1 6 0 0} \boldsymbol{€} \text { per installed } \mathbf{k W p} \text { in } 2013 \text {, } \\
\text { depending on size of the whole unit. } \\
\text { PV grid parity was reached beginning of } 2012 \\
\text { (without storage). }\end{array}$ & $\begin{array}{l}\text { EUROSTAT, } \\
\text { solarwirtschaft.de, } \\
\text { PVparity.eu, }\end{array}$ \\
\hline $\begin{array}{l}\text { Economic and grid impact of } \\
\text { RES }\end{array}$ & $\begin{array}{l}\text { - Estimated additional costs of grid integration of } \\
\text { PV at high penetration levels }(18 \%) \text { : } \\
\mathbf{2 . 4 7} \mathbf{c} € / \mathbf{k W h} \text {. } \\
\text { Possible reduction with demand response } \\
\text { measures/SC to } \mathbf{1 . 8 5} \mathbf{c} \boldsymbol{€} / \mathbf{k W h} \text {. }\end{array}$ & PVparity.eu \\
\hline
\end{tabular}


Case Study: United Kingdom

Summary: UK has a low PV penetration. UK's 2020 National Energy Plan PV objectives are overachieved. UK regulatory framework remunerates production generally (generation tariff) and the feed in by an export tariff. This supports SC. Retail energy prices are relatively high in comparison. Grid parity of PV is foreseen for 2020.

\begin{tabular}{|c|c|c|}
\hline Case Study SC & United Kingdom & Sources \\
\hline Key facts & $\begin{array}{l}\text { PV national target 2020: } 2.68 \mathrm{GWp} \\
\begin{aligned} \text { PV installed: } 5.1 \mathrm{GWp} \text { (end 2014) } \\
\text { o } \text { Residential: } 25 \% \\
\text { o } \% \text { Ground mounted: } 39 \% \\
0 \quad \text { Commercial: } 34 \% \\
0 \quad \text { Industrial: } 2 \%\end{aligned}\end{array}$ & $\begin{array}{l}\text { gov.uk, } \\
\text { epia.org }\end{array}$ \\
\hline Policies relevant to $\mathrm{SC}$ & $\begin{array}{l}\text { - Support for RES: a derivative of FiT schemes: } \\
\text { o Generation Tariff for ALL the energy } \\
\text { produced from RES between } 13.5^{*} \mathrm{c} € / \mathrm{kWh} \\
\text { and } 19.8^{*} \mathrm{c} € / \mathrm{kWh} \text { depending on size. } \\
\text { o Export Tariff additionally for electricity } \\
\text { supplied to the grid. } \\
\text { - VAT reduction from } 20 \% \text { to } 5 \% \text { and tax reductions } \\
\text { for new installations on residential buildings. } \\
\text { Exemption from CCL tax for owners of PV electricity } \\
\text { generation systems in the industrial, commercial, } \\
\text { agricultural, public service sectors. }\end{array}$ & gov.uk \\
\hline Relevant market data & 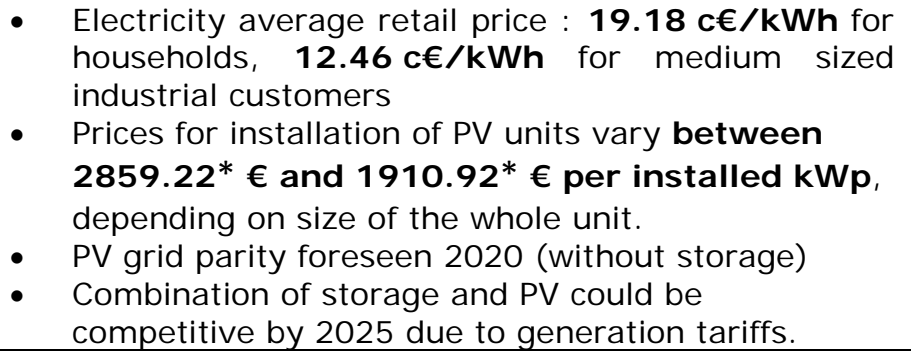 & $\begin{array}{l}\text { EUROSTAT, } \\
\text { gov.uk, } \\
\text { PVparity.eu, } \\
\text { themal.de }\end{array}$ \\
\hline Economic and grid impact of RES & 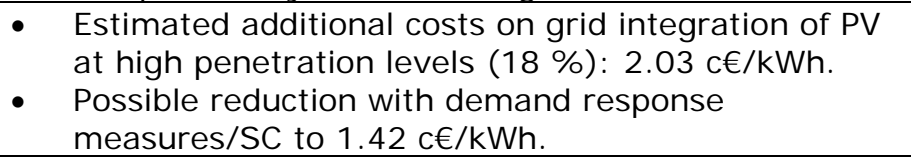 & PVparity.eu \\
\hline
\end{tabular}

\footnotetext{
*Exchange rate of May 18, 2015.
} 


\section{ANNEX II: Modelling the impact of SC on the German wholesale market}

\section{Introduction}

In this section the impact of self-consumption strategies in reference households with a reference electricity demand and a typical photovoltaic rooftop system combined with and without electricity storage system is evaluated based on an optimizing modelling approach with the E2M2 electricity market model. A battery storage system is used to increase the share of self-consumed electricity. Private households in Germany have fixed prices for electricity from the grid and a fixed remuneration of feed-in by PV. Consequently, the storage commitment is not adapted to market conditions. However, due to price compounds, grid fees and taxation, self-consumption is more attractive than feed-in. Therefore self-consumption by prosumers (prosumer: market participant who is producer and consumer at the same time. In this study: private households with a solar power system for self-consumption and grid injection of electricity) increased in recent years so that a share of $35 \%$ domestic prosumers (which corresponds to 4.76 mio. households) of the total installed PV in Germany in 2030 is assumed. This development is not necessarily social-welfare optimized. Variations of self-consumption as described in the following sections are implemented exogenously in the analysis via adapted standard demand profiles and resulting feed-in profiles for PV. To identify effects of specific strategies for selfconsumption and storage it is assumed that all prosumers follow the same strategy at the same time and have the same standardized demand profiles.

Model formulation and framework

The long-term development of the electricity market is analysed by applying the multiregional fundamental European electricity market model E2M2. Power plant investments and unit commitments are endogenously determined in consideration of physical transmission restrictions to cover inelastic demand at all times with a recursive cost minimizing optimization approach. The model is formulated as a linear program and implemented in the General Algebraic Modeling System (GAMS). CPLEX is used as solver. The basic model equations are described in (Sun 2013).

\section{Scenario description}

\section{Model configuration}

In this study the model is used to analyze the impact of self-consumption of German households on the electricity market in a scenario for 2030 with high penetration of renewables and PV. The focus is targeted on the power system of Germany and that of the neighboring countries. Germany and Austria are considered as single regions. France, Benelux, Denmark, Norway, Sweden, Poland, Czech Republic, Italy and Switzerland are aggregated on the basis of their cardinal direction to the electrical nodes Western-, Eastern-, Northern- and Southern Europe to consider the electricity exchange within the European electricity market. In order to analyse short-term variations of synthetic photovoltaic feed-in profiles and of demand profiles caused by different storage strategies a year was modelled with $8,760 \mathrm{~h}$.

Variations of electricity self-consumption

To assess the impact of electricity self-consumption a synthetic PV generation profile based on standard records of a typical year was used. The profile was scaled to the electricity output of a $5 \mathrm{kWp}$ residential rooftop system under German solar irradiation conditions. The resulting electricity output accounts for $4,500 \mathrm{kWh}_{\mathrm{el}}$ (900 full load hours) and equals the annual electricity demand of the typical household. To quantify the effect on the wholesale market, four different PV configurations were considered.

- $\quad$ REF: A reference PV system without storage and no self-consumption feeding the produced electricity into the grid

- SC: A PV system without storage covering the electricity demand (self-consumption) during daytime. The surplus energy is fed into the grid.

- $\quad$ SC-CC: A PV system with a LFP storage system and a subsequent and chronological charging strategy at the time of demand exceeding generation. The surplus energy is fed into the grid.

- SC-GR: A PV system with storage operating in grid-relief operation mode. The surplus energy is fed into the grid.

Details of the storage strategies are explained hereinafter. 
Self-consumption with a battery storage at chronological operation strategy (SC-CC)

To increase the self-consumption rate a Li-Ion battery system with a usable storage capacity of $3 \mathrm{kWh}$ is added to the rooftop system. The storage control operates in chronological charging and discharging mode. This means that the surplus energy exceeding the load is directly fed into the storage. When the storage is filled up the surplus energy is subsequently fed into the electricity grid. Analogously, the storage is discharged chronologically and until the complete depletion of the battery at the moment when the load exceeds the PV electricity generation. This storage management strategy is also described in (Hoppmann et al. 2014).

\section{Self-consumption with a battery storage at grid-relief operation strategy (SC-GR)}

As a precondition we assumed a perfect foresight. This enables the storage control to realize a grid serving friendly feed-in and consumption of electricity. The "grid relief" storage strategy operates by cutting the peaks of the solar electricity generation to feed the storage during daytime and discharges the storage to balance demand peaks at times when the PV system is offset (see figure - red and green columns). The ideal storage management strategy is also described in (Moshövel et.al. 2014). To compare the results of this strategy the same self-consumption rate as in the aforementioned case of the "chronological charging strategy" was assumed.

\section{Scenario parameters}

Data on power plants are based on (Platts 2012) and (Bundesnetzagentur 2014). The development of economic parameters (Invest, O\&M, fuel cost, $\mathrm{CO}_{2}$-cost) for conventional power plants and exogenously set development paths of RES are aligned to the assumptions of the trend scenario in (Schlesinger et.al. 2014) and targets in (Beurskens et al. 2011). Inherent exogenous electricity feed-in profiles of fluctuating RES are based on standard records of a typical year. The net electricity demand in Germany is defined as the used electrical energy of consumers after self-consumption of power plants and prosumers as well as transmission losses. It is aligned to (German transmission system operators 2014). The development of the net electricity demand in the scenarios is shown in Table 1. Rational curtailment of electricity feed-in by fluctuating RES is not allowed in this model configuration to show the straight market effects of the storage strategies.

Table 1: Scenario variations of the electricity demand in Germany in 2030

\begin{tabular}{llllll}
\hline Scenario 2030 & & REF & SC & SC-CC & SC-GR \\
\hline Net electricity demand & {$\left[\mathrm{TWh}_{\mathrm{el}}\right]$} & 535.20 & 525.06 & 521.34 & 521.34 \\
Self-consumption households & {$\left[\mathrm{TWh}_{\mathrm{el}}\right]$} & 0.00 & 10.14 & 13.86 & 13.86 \\
Electricity from PV to grid & {$\left[\mathrm{TWh}_{\mathrm{el}}\right]$} & 61.20 & 51.06 & 47.34 & 47.34 \\
\hline
\end{tabular}

Cost assumptions for small-scale Lithium-Ferrophosphate battery storage systems (LFP)

As a reference small-scale storage option a LFP battery with a rated capacity of $3 \mathrm{kWh}$, a depth of discharge of $100 \%$ and a lifetime durability of 10,000 cycles is used to estimate the additional costs, not included in the electricity market model calculation. The annual costs for the additional storage system in the SC-CC and SCGR variation for each household is calculated with $88.44 € / a$, including a specific CAPEX of $250 € / a$, an OPEX of $20 € / a$ and a discount rate of $7.5 \%$. The lifetime of the storage system amounts to 20 years at assumed 500 charge cycles per year. This cost assumptions are based on the data in (J ülch et.al. 2015).

\section{Results}

Residual demand and grid-injection profiles of reference households

The maximum in PV feed-in of a single household in the REF variation was about $3.5 \mathrm{~kW}$. In the SC and SC-CC variation the PV feed-in could be reduced to a maximum of $2.84 \mathrm{~kW}$ and in the SC-GR variation to a maximum of $2.16 \mathrm{~kW}$. The total maximum PV feed-in in Germany could be reduced from $47.80 \mathrm{GW}$ in the REF variation to 44.74 GW in the SC and the SC-CC variation and to $41.93 \mathrm{GW}$ in the SC-GR variation. Figure 1 shows the impact of the SC-CC and SC-GR charging strategy on a typical summer day in 2030 in Germany to the load profile of a standardized household and the load profile in the German power system. 
I.) Chronological charging strategy (SC-CC)

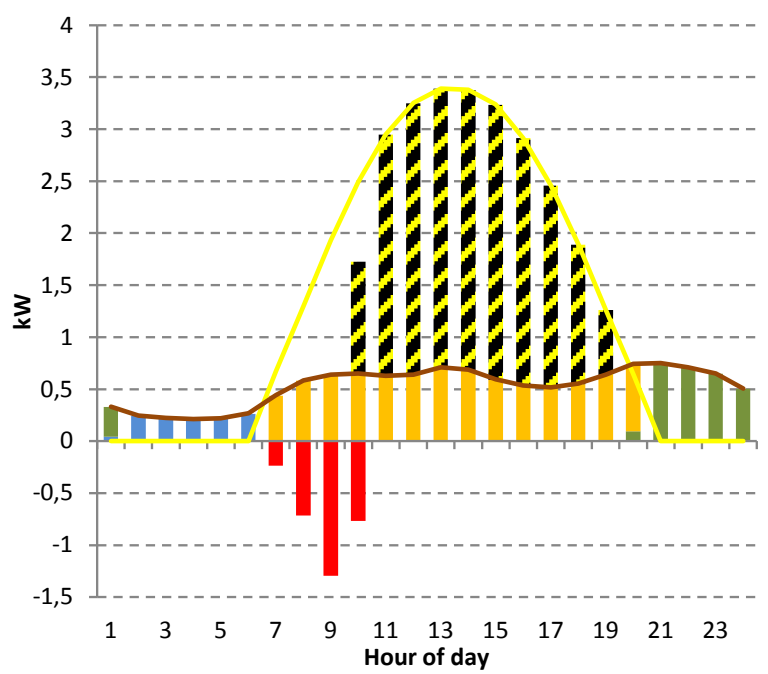

I.) Electric load profile SC-CC

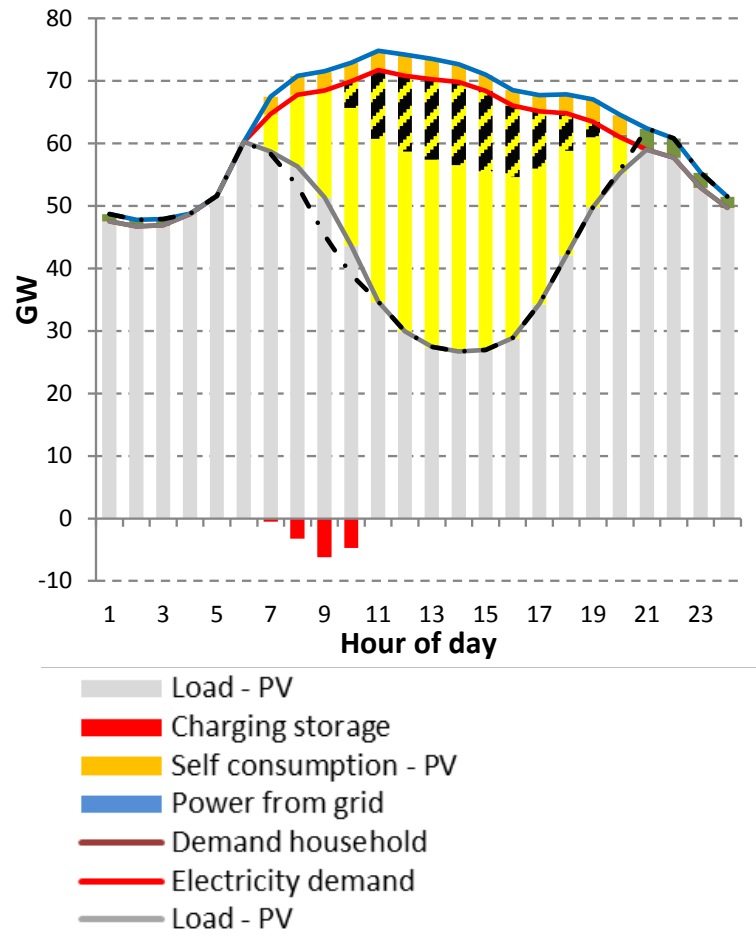

II.) Grid-relief charging strategy (SC-GR)

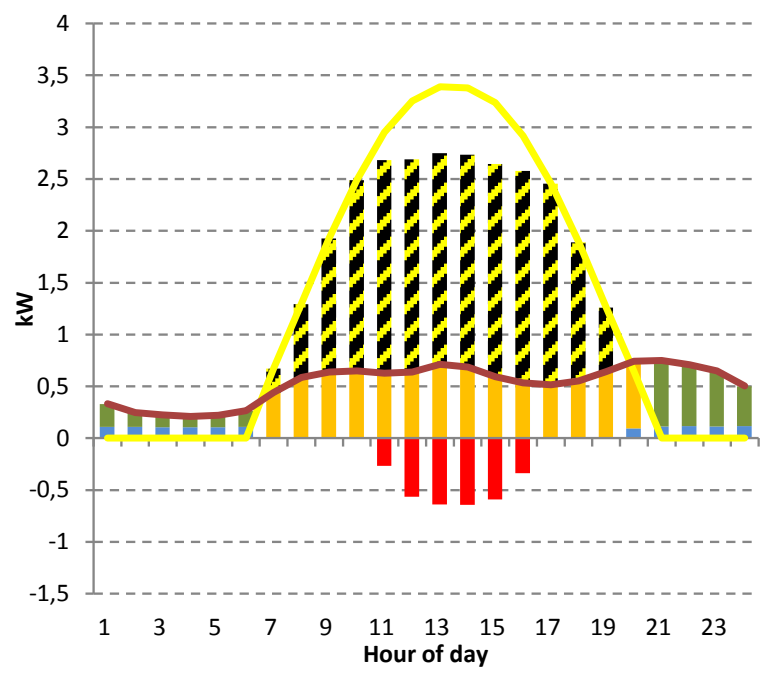

I.) Electric load profile SC-GR

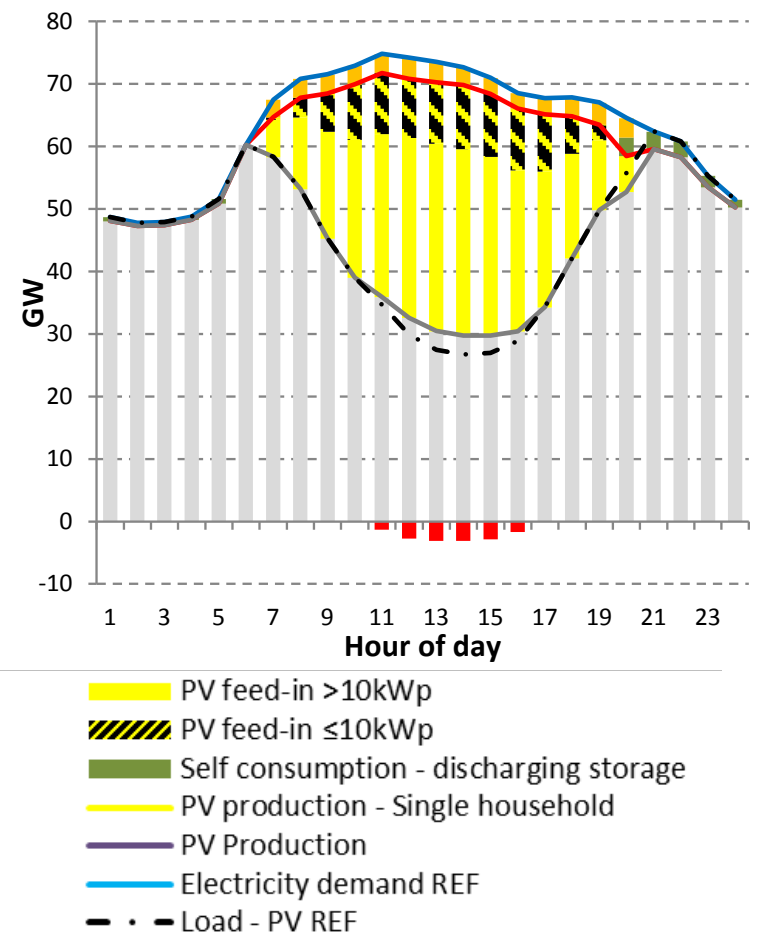

Figure 1: Capacities and load profiles for different storage operation strategies in the SC-CC and SCGR scenario variations at a typical summer day in 2030 in the German electricity system.

I mpacts of PV self-consumption on the electricity market

The REF and the SC variation have the same system costs in the electricity market calculation since there is no change of the residual load and consequently no deviation in unit commitment. In the SC-CC and SC-GR variation the annual cost of $\mathbf{4 2 0 . 9 6}$ million Euros for the small-scale LFP storage systems in households have to be added to the model result from E2M2.

In both variations with storage, the saving in the total system could not cover the additional spending for the storage units. The savings in the SC-GR variation are 174.86 million Euros beyond the savings in the SC-CC 
variation. Table 2 shows the impacts of the scenario variations on the deviation of system costs from the selfconsumption variations to the REF variation.

Our analysis considers only the effects of different self-consumption strategies on the wholesale market, however additional cost saving potential can be expected at electricity grid level which is not covered in the current analysis. Moreover the household electricity demand structure was derived from an aggregated synthetic load profile, detailed modelling of different household consumption patterns should be considered in further studies.

Table 2: I mpacts of self-consumption on pump storage commitment and total system costs in the German power supply sector for $\mathbf{2 0 3 0}$

\begin{tabular}{|c|c|c|c|c|c|}
\hline Scenario 2030 & & REF & SC & SC-CC & SC-GR \\
\hline Deviation of system costs from REF & & & & & \\
\hline System cost E2M2 & {$\left[€ / a 1^{6}\right]$} & 0.00 & 0.00 & -151.86 & -326.72 \\
\hline Annual Cost LFP storage & {$\left[€ / a \quad 10^{6}\right]$} & 0.00 & 0.00 & 420.96 & 420.96 \\
\hline Deviation Total cost 2030 & {$\left[€ / a 1^{6}\right]$} & 0.00 & 0.00 & 296.10 & 94.24 \\
\hline
\end{tabular}

